International Journal of Current Advanced Research

ISSN: O: 2319-6475, ISSN: P: 2319 - 6505, Impact Factor: SJIF: 5.995

Available Online at www.journalijcar.org

Volume 6; Issue 3; March 2017; Page No. 2654-2656

DOI: http://dx.doi.org/10.24327/ijcar.2017.2656.0067

Research Article

\title{
DETECTION OF HLY-A GENE ENCODING ALPHA HEMOLYSIN IN URINARY ISOLATES OF ESCHERICHIA COLI FROM TERTIARY CARE HOSPITAL IN KANCHEEPURAM DIST
}

\author{
Reshma Harikrishnan ${ }^{1}$ and Gopinath. $P^{2 *}$ \\ ${ }^{1} 2^{\text {nd }}$ Year BDS, Saveetha Dental College and Hospitals, Chennai, India \\ ${ }^{2}$ Department of Microbiology Saveetha Dental College and Hospitals, Chennai, India
}

\section{A R T I C L E I N F O}

Article History:

Received $20^{\text {th }}$ December, 2016

Received in revised form $16^{\text {th }}$ January, 2017

Accepted $6^{\text {th }}$ February, 2017

Published online $28^{\text {th }}$ March, 2017

\section{Key words:}

hlyA gene, alpha hemolysin, Escherichia coli,

PCR, Urinary Tract Infections

\begin{abstract}
A B S T R A C T
Alpha hemolysin is a toxin secreted by Escherichia coli causes cell death by binding with the outer membrane, with subsequent oligomerization of the toxin monomer and waterfilled channels. These are responsible for osmotic phenomena, cell depolarization, and loss of vital molecules, leading to its demise. A total of 20 clinical isolates of E. coli were screened for the presence of hlyA gene by PCR. We have observed $60 \%$ positivity among our isolates. There are several virulent factors that are associated with urinary tract infections, production of alpha hemolysin one amongst those factors also play a crucial role in pathogenesis of UTI.
\end{abstract}

Copyright $\odot 2017$ Reshma Harikrishnan and Gopinath. P. This is an open access article distributed under the Creative Commons Attribution License, which permits unrestricted use, distribution, and reproduction in any medium, provided the original work is properly cited.

\section{INTRODUCTION}

Escherichia coli causes different infections that possess numerous virulence factors, including hemolysin production. E. coli $\alpha$-hemolysin (HlyA) produces large, clear zones of hemolysis around colonies on blood agar. The hemolysin is present in cell-free filtrates and is the best characterized member of the RTX (repeat in toxin) toxin family ${ }^{[1]}$. HlyA lyses cells by the creating pores in the target cell membrane and affects erythrocytes, leukocytes ${ }^{[3]}$, and renal tubular cells ${ }^{[2]}$. It also acts on polymorphonuclear granulocytes liberates leukotrienes, histamine, and ATP ${ }^{[4]}$ and is neutralized by specific antiserum.

Sublytic concentrations of this toxin induce various reactions in eukaryotic target cells which lead to cellular dysfunction ${ }^{[5]}$. The hly operon required for synthesis and extracellular secretion of E. coli hemolysinwhich contains four structural genes arranged in the order hlyC, hlyA, hlyB, and hlyD ${ }^{[6]}$. Gene hlyA encodes $110-\mathrm{kDa}$ hemolysin protein (pro-HlyA) which represents an inactive precursor of the mature toxin. The conversion of pro-HlyA to the hemolytically active hemolysin (HlyA) takes place in the cytoplasm of E. coli and is mediated by HlyCgene ${ }^{[2]}$. With this background our aims to detect the presence of hlyA gene among urinary isolates of $\mathrm{E}$. coli.

*Corresponding author: Gopinath. $\mathbf{P}$

Department of Microbiology Saveetha Dental College and Hospitals, Chennai, India

\section{MATERIALS AND METHODS}

\section{Bacterial isolates}

A total of 20 non repetitive urinary isolates of Escherichia coli were collected from Saveetha Medical College and Hospitals, Chennai. They were processed for a battery of standard biochemical tests and confirmed. Isolates were preserved in semisolid trypticase soy broth stock and were stored at $4{ }^{\circ} \mathrm{C}$ until further use.

\section{Antibiotic susceptibility testing}

Antibiotic susceptibility test was determined for these isolates to routinely used antibiotics such as ampicillin, amoxicillin, amikacin, norfloxacin, ceftazimide, cefotaxime, ciprofloxacin and gentamicin, imipenem as by Kirby Bauer disc diffusion $\operatorname{method}^{[7]}$.

\section{Detection of hlyA gene in E.coli}

Escherichia coli isolates were detected for the presence of hlyA gene by PCR analysis. Detection of the gene was carried out using primer as depicted in table 1. Bacterial DNA was extracted by boiling lysis method. $1 \mu \mathrm{L}$ of DNA extract was used as template for PCR reaction. The reaction mixture contained $1 \mathrm{mM}$ of $\mathrm{Mgcl}_{2} 0.2 \mathrm{mM}$ dNTP mix and $0.8 \mu \mathrm{M}$ of hlyA gene with $0.5 \mathrm{U}$ of Taq polymerase (New England Biolabs) in a 1x PCR buffered reaction. A positive control of E.coli with hlyA gene was also included in this study. PCR amplification was carried out using thermal cycler (Eppendorf) with the following cycling condition. Initial denaturation at $98^{\circ} \mathrm{C}$ for $5 \mathrm{~min}$ and 30 cycles for $30 \mathrm{~s}, 70^{\circ} \mathrm{C}$ for 
$30 \mathrm{~s}$ and $68^{\circ} \mathrm{C}$ for $60 \mathrm{~s}$, followed by a final extension of $6 \mathrm{~min}$ at $75^{\circ} \mathrm{C}$. PCR products were resolved in $2 \%$ agarose gel. A $100 \mathrm{bp}$ ladder was including in all the gel analysis ${ }^{[8]}$.

Table 1 Gene sequencing of hlyA gene

\begin{tabular}{ccc}
\hline Primer & Primer sequence & Product size \\
\multirow{2}{*}{ hlyA } & AAC AAG GAT AAG CAC TGT TCT GGC T & $172 \mathrm{bp}$ \\
& ACC ATA TAA GCG GTC ATT CCC GTC A & 172 \\
\hline
\end{tabular}

\section{RESULTS}

\section{Sample wise distribution of clinical isolates of E.coli}

Of the 20 clinical isolates of E.coli, 12/20 (60\%) were from acute urinary tract infections and $8 / 20$ (40\%) were from chronic urinary tract infections. Figure 1 depicts the sample wise distribution of clinical isolates of E.coli.

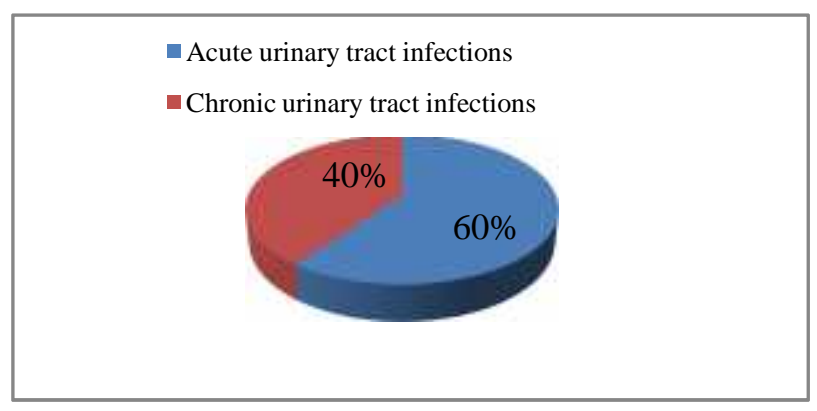

Figure 1 Sample wise distribution of urinary isolates of E.coli

\section{Antibiotic susceptibility testing}

In our isolates, we have found increased percentage 14/20 (70\%) of isolates showed sensitivity to amikacin followed by gentamicin, which showed sensitivity of 9/20 (45\%). 80- 90\% of E.coli isolates showed resistance to cephalosporin group of drugs. 6/20 (30\%) were found to be resistant to imipenem. However, we have observed an elevated level of resistance to other routinely used antibiotics. The detailed resistant pattern of E.coli isolates is shown in table 2.

Table 2 Showing antibiotic sensitivity pattern of E. coli

\begin{tabular}{cccc}
\hline Antibiotics & $\begin{array}{c}\text { Sensitivity(20) } \\
(\boldsymbol{\%})\end{array}$ & $\begin{array}{c}\text { Intermediate (20) } \\
(\mathbf{\%})\end{array}$ & $\begin{array}{c}\text { Resistant(20) } \\
(\mathbf{\%})\end{array}$ \\
\hline Ampicillin & 5 & 0 & 95 \\
Amoxicillin & 5 & 0 & 95 \\
Ceftazidime & 10 & 10 & 80 \\
Cefotaxime & 5 & 5 & 90 \\
Amikacin & 70 & 10 & 20 \\
Gentamicin & 45 & 20 & 35 \\
Norfloxacin & 15 & 15 & 70 \\
Ciprofloxacin & 20 & 5 & 75 \\
Imipenem & 70 & 0 & 30 \\
\hline
\end{tabular}

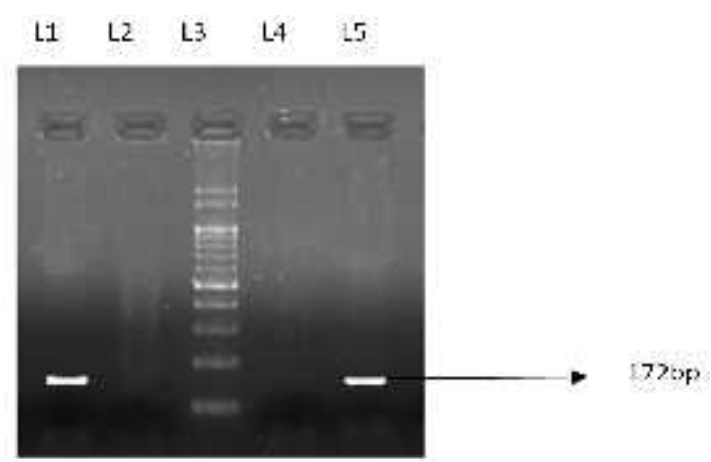

Figure 2 Representative gel picture showing positive for hlyA gene

\section{Result of hlyA gene in E.coli}

$12 / 20(60 \%)$ clinical isolates of urinary isolates of E.coli was found to harbor hlyA gene.

\section{DISCUSSION}

The most frequently occuring extraintestinal infections caused by E. coli are usually urinary tract infections. The -hemolysin is present in about 25 to $56 \%$ of isolated strains from urinary tract infections ${ }^{[9]}$, similar to the previous studies we also got increased percentage of $\mathrm{E}$. coli isolates from urinary tract.Study done by Kerenyi and colleagues found that, the presence of the sheA gene in normal fecal strains is higher $(85.4 \%)$ than in the isolates from urinary tract infection $(47.1 \%)$. Wherein, the occurrence of hlyA gene in normal fecal isolates was $7.3 \%$, similar to that previously reported ${ }^{[10]}$. Similarly we also found $12 / 20(60 \%)$ of our uropathogenicE.coli were showed positive for hlyAgene. Though it is acknowledged that the -hemolysin is an important virulence factor to the pathogenic profile of E. coli, the role played by the silent hemolysinPSheA in disease is still unknown.

\section{CONCLUSION}

From our study we have observed the presence of hlyA gene encodes for alpha hemolysin production. There are several virulent factors are associated with urinary tract infections, production of alpha hemolysin also plays a crucial role in pathogenesis of UTI. To conclude this more number of isolates with different sets of genes for other hemolysins needs to be detected.

\section{References}

1. Welch RA, Forestier C, Lobo A, Pellett S, Thomas W, Rowe J. The synthesis and function of the Escherichia coli hemolysin and related RTX exotoxins. FEMS Microbiol Immunol. 5; 1992:29-36.

2. Keane, Welch WFR, Gekker G, and Peterson PK. Mechanism of Escherichia coli alpha-hemolysininduced injury to isolated renal tubular cells. Am J Pathol. 126; 1987:350-357.

3. Bhakdi, Greulich SS, Muhly M, Eberspacher B, Becker.H, Thiele A, and Hugo F. Potent leukocidal action of Escherichia coli hemolysin mediated by permeabilization of target cell membranes. $J$ Exp Med 169; 2989:737-754.

4. Konig, Ludwig BA, Goebel W, and Konig W. Pore formation by the Escherichia coli alphahemolysin: role for mediator release from human inflammatory cells. Infect Immun. 62; 1994:4611-4617.

5. Bhakdi, S, and Martin E. Superoxide generation by human neutrophils induced by low doses of Escherichia coli hemolysin. Infect Immun. 59; 1991: 2955-2962.

6. Felmlee, Pellett TS, and Welch RA. Nucleotide sequence of an Escherichia coli chromosomal hemolysin. J Bacteriol. 163; 1985:94-105.

7. Clinical and Laboratory Standards Institute. Performance Standards for Antimicrobial Disk Tests; Approved Standards; Doucement M2-A9, 2015, $9^{\text {th }}$ ed., Vol 26. Wayne, PA: CLSI.

8. Kaczmarek A, Budzynska A, Gospodarek E. Prevalence of genes encoding virulence factors among 
Escherichia coli with $\mathrm{K} 1$ antigen and non-K1 E. coli strains. Journal of Medical Microbiology 61; 2012:1360-1365.

9. Minshew, Jorgensen BHJ, Swanstrum M, GrootesReuvecamp GA, and Falkow S. Some characteristics of Escherichia coli strains isolated from extraintestinal infections of humans. J Infect Dis. 137; 1978:648-654.

Please cite this article in press as:

Reshma Harikrishnan and Gopinath. P (2017), Detection Of Hly-A Gene Encoding Alpha Hemolysin In Urinary Isolates Of Escherichia Coli From Tertiary Care Hospital In Kancheepuram Dist, International Journal of Current Advanced Research, 6(3), pp. 2654-2656.

http://dx.doi.org/10.24327/ijcar.2017. 2656.0067
10. Johnson JR. Virulence factor in Escherichia coli urinary tract infection.Clin Microbiol Rev. 4; 1991:80128. 